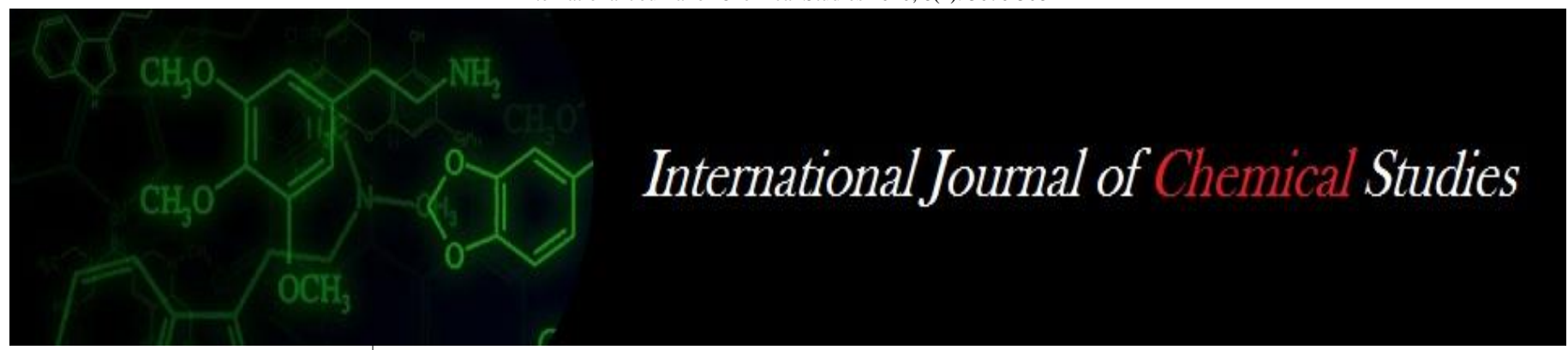

P-ISSN: 2349-8528

E-ISSN: 2321-4902

www.chemijournal.com

IJCS 2020; 8(1): 3076-3084

(C) 2020 IJCS

Received: 11-11-2019

Accepted: 15-12-2019

\section{Pradeepkumar CM}

Department of Floriculture and

Landscape Architecture, College

of Horticulture, Mudigere,

Chikmagalur, Karnataka, India

Chandrashekar SY

Department of Floriculture and

Landscape Architecture, College

of Horticulture, Mudigere,

Chikmagalur, Karnataka, India

\section{Kavana GB}

Department of Floriculture and Landscape Architecture, College of Horticulture, Mudigere,

Chikmagalur, Karnataka, India

\section{Supriya BV}

Department of Floriculture and Landscape Architecture, College of Horticulture, Mudigere,

Chikmagalur, Karnataka, India

Corresponding Author:

Pradeepkumar CM

Department of Floriculture and

Landscape Architecture, College

of Horticulture, Mudigere,

Chikmagalur, Karnataka, India

\section{A review on role and use of gibberellic acid $\left(\mathrm{GA}_{3}\right)$ in flower production}

\author{
Pradeepkumar CM, Chandrashekar SY, Kavana GB and Supriya BV
}

DOI: https://doi.org/10.22271/chemi.2020.v8.i1au.8738

\begin{abstract}
The plant growth regulators consist of a large group of naturally occurring or synthetically produced organic chemicals and considered as helping tool in the modern production system of flowering plants. Plant growth regulators are being used by the commercial growers of ornamental plants as a part of cultural practice. Plant growth regulators have quicker impact on vegetative as well as flower yield of flowering crops. Among them, Gibberellic Acid $\left(\mathrm{GA}_{3}\right)$ plays important role in flower production, quality and yield of the flower crops. The Gibberellic Acid $\left(\mathrm{GA}_{3}\right)$ is a tetracyclic di-terpenoid compound and a plant hormone stimulating plant growth and development. GAs stimulate seed germination, trigger transitions from meristem to shoot growth, juvenile to adult leaf stage, vegetative to flowering, determines sex expression and grain development along with an interaction of different environmental factors viz., light, temperature and water. The production of flower with good quality flowers has greater importance. Their exogenous application helps to improve the different economically important and market desirable characteristics of flower plants. As it have various advantages like less time consuming to treat the plant and environment friendly. Use of growth regulators in flowering crops must be specific their action and toxicologically and environmentally safe. The physiological activities of flowering crops regulate by the application of growth regulators like $\mathrm{GA}_{3}$ has finally affect the growth and flower production in flowering crops. There are various factors contributing to the efficacy of plant growth regulators among them the method of application plays a key role in determining the effectiveness of plant growth regulators, as they can be effective if properly absorbed by plants. The physiological activities of flowering crops regulate by the application of growth regulators and finally affect the growth and flower production in flowering crops. In this review, we have summarised critically on the role and use of Gibberellic Acid $\left(\mathrm{GA}_{3}\right)$ on flower production of commercial crops.
\end{abstract}

Keywords: gibberellic acid, growth, flowering, yield and economics

\section{Introduction}

Floriculture has been emerging as a future thrust industry in India and referred as tomorrow's green cultivation. Importance of cut flowers in international flower market makes the growers to take up its cultivation in India. The production of flower crop using growth regulator plays an important role in higher production and quality flowers to market. Plant growth regulators are being used by the commercial growers of ornamental plants as a part of cultural practice. Plant growth regulators have quicker impact on vegetative as well as flower yield of flowering crops. As it have various advantages like less time consuming to treat the plant and environment friendly. There are various factors contributing to the efficacy of plant growth regulators among them the method of application plays a key role in determining the effectiveness of plant growth regulators, as they can be effective if properly absorbed by plants. Use of growth regulators in flowering crops must be specific their action and toxicologically and environmentally safe. The physiological activities of flowering crops regulate by the application of growth regulators and finally affect the growth and flower production in flowering crops.

The Gibberellic Acid $\left(\mathrm{GA}_{3}\right)$ is a tetracyclic di-terpenoid compound and a plant hormone stimulating plant growth and development. GAs stimulate seed germination, trigger transitions from meristem to shoot growth, juvenile to adult leaf stage, vegetative to flowering, determines sex expression and grain development along with an interaction of different environmental factors viz., light, temperature and water. 
The production of flower with good quality flowers has greater importance. Their exogenous application helps to improve the different economically important and market desirable characteristics of flower plants. As it have various advantages like less time consuming to treat the plant and environment friendly. Use of growth regulators in flowering crops must be specific their action and toxicologically and environmentally safe. The physiological activities of flowering crops regulate by the application of growth regulators like $\mathrm{GA}_{3}$ has finally affect the growth and flower production in flowering crops. There are various factors contributing to the efficacy of plant growth regulators among them the method of application plays a key role in determining the effectiveness of plant growth regulators, as they can be effective if properly absorbed by plants. The physiological activities of flowering crops regulate by the application of growth regulators and finally affect the growth and flower production in flowering crops. In this review, we have summarised critically on the role and use of Gibberellic Acid $\left(\mathrm{GA}_{3}\right)$ on flower production of commercial crops.

Floriculture has been emerging as a future thrust industry in India and referred as tomorrow's green cultivation. Importance of cut flowers in international flower market makes the growers to take up its cultivation in India. The production of flower crop using growth regulator plays an important role in higher production and quality flowers to market. Plant growth regulators are being used by the commercial growers of ornamental plants as a part of cultural practice. Plant growth regulators have quicker impact on vegetative as well as flower yield of flowering crops. As it have various advantages like less time consuming to treat the plant and environment friendly. There are various factors contributing to the efficacy of plant growth regulators among them the method of application plays a key role in determining the effectiveness of plant growth regulators, as they can be effective if properly absorbed by plants. Use of growth regulators in flowering crops must be specific their action and toxicologically and environmentally safe. The physiological activities of flowering crops regulate by the application of growth regulators and finally affect the growth and flower production in flowering crops.

The Gibberellic Acid $\left(\mathrm{GA}_{3}\right)$ is a tetracyclic di-terpenoid compound and a plant hormone stimulating plant growth and development. GAs stimulate seed germination, trigger transitions from meristem to shoot growth, juvenile to adult leaf stage, vegetative to flowering, determines sex expression and grain development along with an interaction of different environmental factors viz., light, temperature and water.

Gibberellins commonly known as Gibberellicacids had been discovered much earlier in Japan. Rice farmers of Japan had long known of a fungal disease called foolish seedling or bakanae disease that causes rice plants to grow taller and eliminated seed production. Plant pathologists found that these symptoms in rice plant were induced by a chemical secreted by a pathogenic fungus, Gibberella fujikuroi. Upon culturing this fungus in the laboratory and analyzing the culture filtrate enabled Japanese scientists in the 1930s to obtain impure crystal of two fungal "compounds" possessing plant growth promoting activity. One of these, was isolated from the fungus Gibberella, was named gibberellin A. In 1950s scientists of Tokyo University separated and characterized 3 different gibberellins from gibberellin $\mathrm{A}$ sample, and named them gibberellin $A_{1}$, gibberellin $A_{2}$ and gibberellin $A_{3}$. The numbering system for gibberellins used in the past 50 years builds on this initial nomenclature of gibberellins $\mathrm{A}_{1}\left(\mathrm{GA}_{1}\right), \mathrm{GA}_{2}$, and $\mathrm{GA}_{3}$.

In the same year, 2 research groups, one at Imperial Chemical Industries in Britain and other at the US Department of Agriculture (USDA) in Illinois, elucidated the chemical structure of the compound that they had purified from Gibberella culture filtration and named gibberellic acid. This compound was later shown to be identical to the gibberellin isolated by the Japanese scientist. For this $\mathrm{GA}_{3}$ is also referred to as gibberellic acid. $\mathrm{GA}_{3}$ is the principal component in Gibberella culture. The $\mathrm{GA}_{3}$ is the most frequently produced GA in commercial industrial scale fermentations of Gibberella for agronomic, horticultural and other scientific uses. Identification of a GA from a plant extract was first made in 1958 with the discovery of $\mathrm{GA}_{1}$ from immature seeds of runner bean (Phaseolus cocineus). As more and more GAs from Gibberella and different plant sources were characterized, a scheme was adopted in 1968 to number them $\left(\mathrm{GA}_{1}-\mathrm{GA}_{4}\right)$, in chronological order of their discovery.

\section{Influence of GA3 on Growth parameters of flower crops}

Sadanand et. al. (2000) ${ }^{[40]}$ reported increased plant height, shoot length and maximum number of leaves per plant with the application of $\mathrm{GA}_{3} @ 200$ ppm in rose cv. First Red.

Beena (2000) ${ }^{[6]}$ investigated the effect of growth regulators on growth and flowering of Anthurium andreanum Linden. The varieties used were Liver red (L.R), Ceylon Red (C.R) and Kalympong Orange (K.O). Three growth regulators namely Gibberellic acid $\left(\mathrm{GA}_{3}\right)$, Tri Iodo Benzoic Acid (TIBA) and Kinetin (K) were used at 100, 300 and 500 ppm concentrations. The results of the experiments revealed that the growth regulators had significant effect on most of the characters under study. The maximum plant height $(69.82 \mathrm{~cm})$ was obtained nine months after the first spray for Kalympong Orange treated with $\mathrm{GA}_{3} @ 500$ ppm and number of leaves per plant (9.00) was recorded by Ceylon Red treated with $\mathrm{GA}_{3} @ 300$ ppm and also Highest number of suckers/plant (4.60) was produced by Kalympong Orange treated with GA @ 500 ppm, obtained nine months after the first spray.

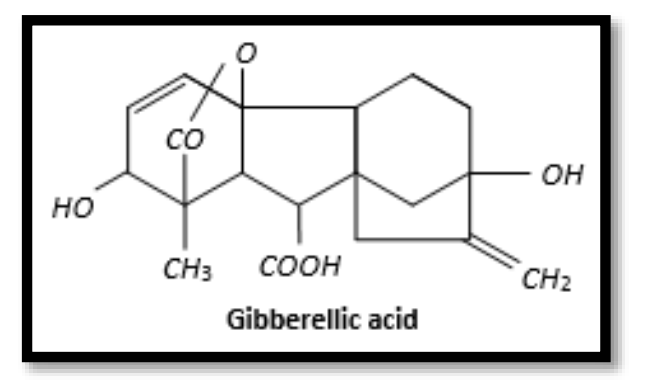

Chandrappa (2002) ${ }^{[9]}$ studied the impact of growth regulators on growth characters of Anthurium cv. Royal Red. Among all the treatments $\mathrm{GA}_{3} @ 750$ ppm recorded maximum plant height $(42.55 \mathrm{~cm})$, leaf area $(248.66 \mathrm{sq} . \mathrm{cm})$ and number of leaves per plant (3.40).

Preeti et al. (2004) ${ }^{[36]}$ studied the effect of different plant growth regulators i.e. $\mathrm{MH}$ (500 ppm and $1000 \mathrm{ppm}), \mathrm{GA}_{3}$ (300 ppm and $500 \mathrm{ppm}$ ), BAP (200 ppm and $400 \mathrm{ppm}$ ), ethylene (500 ppm and $750 \mathrm{ppm})$ and IAA (200 ppm and 300 ppm) on vegetative characters of Anthurium andreanum cv. Agnihotri and they opined that among different plant growth regulators $\mathrm{GA}_{3} @ 500$ ppm recorded maximum plant height $(40.22 \mathrm{~cm})$ which was at par with $\mathrm{GA}_{3} @ 300$ ppm $(38.08 \mathrm{~cm})$ and BAP @ 400 ppm $(36.63 \mathrm{~cm})$ and minimum $(27.00 \mathrm{~cm})$ 
was recorded by $\mathrm{MH} @ 1000$ ppm, whereas GA 3 @ 500 ppm recorded maximum number of leaves per plant (9.50) which is at par with $\mathrm{GA}_{3} @ 300$ ppm (9.33) and BAP @ 400 ppm (8.17), whereas minimum (5.33) was recorded by control.

Srinivasa (2005) ${ }^{[54]}$ revealed the influence of $\mathrm{GA}_{3}$ on growth of anthurium cv. Mauritius Red. From the experiment it was reported that plants treated with $\mathrm{GA}_{3} @ 300$ ppm recorded maximum plant height $(44.44 \mathrm{~cm})$ and leaf width $(11.19 \mathrm{~cm})$ compared to all other treatments and $\mathrm{GA}_{3} @ 225$ ppm showed maximum number of leaves (13.33) per plant whereas $\mathrm{GA}_{3}$ @300 ppm showed maximum leaf length $(21.00 \mathrm{~cm})$ comparatively.

Panwar et. al. (2006) ${ }^{[32]}$ on tuberose found that foliar application of $\mathrm{GA}_{3} @ 0,25,50,75$ and 100 ppm was done on plants at 4-5 leaf stage. Among all treatments, application of $\mathrm{GA}_{3}$ at $100 \mathrm{ppm}$ was found best resulting in more number of leaves / plant.

Devadanam et. al. (2007) ${ }^{[16]}$ conducted a trial on the effects of $\mathrm{GA}_{3}(50,100$ or $150 \mathrm{ppm})$ on growth and yield of Polianthes tuberosa. $\mathrm{GA}_{3}$ was sprayed to plants at 30,60 and 90 days after planting significantly enhanced the growth. $\mathrm{GA}_{3}$ @ $150 \mathrm{ppm}$ resulted in the greatest plant height $(59.13 \mathrm{~cm})$.

Ismaeil and Youssef (2008) ${ }^{[21]}$ on Hemerocallis aurantiaca concluded that all $\mathrm{GA}_{3}$ concentrations (50, 100 and $\left.200 \mathrm{ppm}\right)$ significantly increased the number of leaves and fresh and dry weights of leaves when compared with untreated plants "control" in both seasons.

Delvadia et al. (2009) ${ }^{[14]}$ experimented on the effect of different $\mathrm{GA}_{3}$ concentration and frequency on growth, flowering and yield in gaillardia (Gaillardia pulchella Foug.) $c v$. Lorenziana and they opined that maximum plant height $(45.20 \mathrm{~cm})$ was produced when plant treated with $\mathrm{GA}_{3} @ 250$ ppm at single stage and minimum $(22.96 \mathrm{~cm})$ was in control.

Soad et al. (2010) ${ }^{[51]}$ conducted a pot experiment to study the effect of foliar application with benzyl adenine @ 50, 100 and 150 ppm and gibberellic acid @ 100,150 and 200 ppm on the vegetative growth of croton plants. The highest recorded data for plant height of $70.53 \mathrm{~cm}$ was obtained in plants treated with GA 3 @ 200 ppm, whereas 61.48 cm and GA 3 @ 200 ppm produced 261.40 leaves / plant.while, GA 3 @ 200 ppm exhibited highest leaf area $\left(122.71 \mathrm{~cm}^{2}\right)$ which is at par with BA@ @ 150 ppm $\left(117.82 \mathrm{~cm}^{2}\right)$.

Pancholi et al. (2010) ${ }^{[33]}$ done with the experiment on response of Anthurium to foliar application of urea and growth regulators in shade net house and documented that compare to all other combinations (BA, $\mathrm{GA}_{3}$ and Urea, the foliar application of $\mathrm{GA}_{3} @ 150$ ppm recorded significantly maximum number of leaves per plant in anthurium cv. Coralis (5.20) and Patino (4.60) under shade net and GA3 @ 150 ppm enhanced the sucker production per plant in anthurium $c v$. Coralis (1.80) and Patino (1.50) under shade net.

Shinde (2010) ${ }^{[48]}$ concluded that the maximum leaf area plant 1 , leaf area index and leaf area duration $(0.981 \mathrm{~m} 2$ plant- 1 , $3.78 \mathrm{~m}^{2}$ plant $^{-1}$, and $14.04 \mathrm{~m}^{2}$ day $^{-1}$ ) were recorded in plants sprayed with foliar application of $\mathrm{GA}_{3} @ 200$ ppm followed by $\mathrm{GA}_{3} @ 150$ ppm $\left(0.980 \mathrm{~m}^{2}\right.$ plant $^{-1}, 2.54 \mathrm{~m}^{2}$ plant $^{-1}$, and $13.37 \mathrm{~m}^{2}$ day $^{-1}$ in chrysanthemum (Chrysanthemum morifolium Ramat.) cv. IIHR-6 under middle Gujarat conditions.

Sharifuzzaman et al. (2011) ${ }^{[44]}$ studied the effect of $\mathrm{GA}_{3}$, $\mathrm{CCC}$ and $\mathrm{MH}$ on vegetative growth, flower yield and quality of chrysanthemum and revealed the highest number of leaves (60.00) was produced by the application of $\mathrm{GA}_{3} @ 150 \mathrm{ppm}$ as a foliar spray, however CCC @ 800 ppm showed minimum (22.00) number of leaves/plants. The highest number of suckers (20.00) per plant was produced when plants were treated with $\mathrm{GA}_{3} @ 150$ ppm followed by $\mathrm{GA}_{3} @ 100$ ppm (18.00), whereas, use of CCC at 600 and $800 \mathrm{ppm}$ produced the lowest number of suckers (7.00 and 6.00, respectively).

Sainath et al. (2012) ${ }^{[41]}$ reported the maximum plant height $(97.28 \mathrm{~cm})$, number of leaves plant ${ }^{-1}(702.43)$ and leaf area plant $^{-1}\left(4497.24 \mathrm{~cm}^{2}\right)$ were recorded in plants sprayed with $\mathrm{GA}_{3} @ 200 \mathrm{ppm}$ at the time of final harvest in annual chrysanthemum (Chrysanthemum coronarium L.).

Muthukumar et al. (2012) ${ }^{[31]}$ studied the influence of various growth regulating chemicals on growth, yield and quality characters of cut rose cv. First Red. The study involved preharvest spraying with gibberellic acid (50 ppm and $100 \mathrm{ppm})$, maleic hydrazide (50 ppm and $100 \mathrm{ppm})$ and salicylic acid (25 ppm and 50 ppm). Gibberellic acid @ 100 ppm as a preharvest spray excreted a significant influence on crop growth and recorded highest mean values for plant height $(76.18 \mathrm{~cm})$, whereas minimum plant height was recorded by maleic hydrazide@100 ppm $(46.77 \mathrm{~cm})$.

Taha (2012) [55] indicated that the effect of some growth regulators on growth, flowering, bulb productivity and chemical composition of Iris plants The highest percentage of the total carbohydrates in the bulbs was obtained by the application of $\mathrm{GA}_{3} @ 750$ ppm followed by CCC @ 1000 and Alar@ 500 ppm.

Aparna (2012) ${ }^{[4]}$ conducted an experiment on the effect of different concentrations of GA3 (0, 200, 300 and $400 \mathrm{ppm})$ on two cultivars (Snowball and Thai Chen Queen) of chrysanthemum. Foliar spray of $\mathrm{GA}_{3} @ 400$ ppm recorded the maximum crop growth rate $\left(0.005 \mathrm{~g}^{-1} \mathrm{~m}^{2} \mathrm{~d}^{-1}\right.$ and $0.18 \mathrm{~g}^{-1} \mathrm{~m}^{2} \mathrm{~d}^{-}$ $\left.{ }^{1}\right)$, relative growth rate $\left(0.020 \mathrm{~g} \mathrm{~g}^{-1} \mathrm{~d}^{-1}\right.$ and $\left.0.056 \mathrm{~g} \mathrm{~g}^{-1} \mathrm{~d}^{-1}\right)$ and total chlorophyll content $\left(1.77 \mathrm{mg} \mathrm{g}^{-1}\right.$ and $\left.1.75 \mathrm{mg} \mathrm{g}^{-1}\right)$ in chrysanthemum (Chrysanthemum morifolium Ramat) cv.s. Snowball and Thai Chen Queen.

Anjali (2013) ${ }^{[3]}$ evaluated the response of $\mathrm{GA}_{3}$ on growth and yield of anthurium (Anthurium andreanum Lind.) under shade net condition. Among the different level of treatment, GA $@$ $600 \mathrm{ppm}$ exhibited the highest plant height $(64.87 \mathrm{~cm})$ which was on par with treatment $\mathrm{GA}_{3} @ 450 \mathrm{ppm}(63.58 \mathrm{~cm})$ and it was lowest $(59.47 \mathrm{~cm})$ in control at 15 months after planting, whereas more number of leaves per plant (6.56), maximum leaf width $(21.83 \mathrm{~cm})$ and highest leaf length $(36.92 \mathrm{~cm})$ was recorded in treatment $\mathrm{GA}_{3} @ 600$ ppm.

Handaragall et al. (2013) ${ }^{[18]}$ studied the effect of $\mathrm{GA}_{3}$ and foliar nutrients along with bio fertilizers on growth and flowering of Anthurium andreanum cv. Tropical Red. The results documented that among the different treatments GA3 @ 100 ppm along with bio-fertilizers significantly increased plant height $(26.43 \mathrm{~cm})$ and also increased the number of leaves per plant (9.73) compare to all other treatments in Anthurium andreanum cv. Tropical Red

Rani and Singh (2013) ${ }^{[37]}$ experimented on the impact of gibberellic acid pre-treatment on growth and flowering of tuberose (Polianthes tuberosa L.) $c v$. Prajwal and they revealed that $\mathrm{GA}_{3} @ 150$ ppm showed maximum plant height $(71.27 \mathrm{~cm})$ and maximum (59.60) number of leaves/plant.

Shanan et al. (2014) ${ }^{[45]}$ studied the response of Celosia cristatacv. Red Velvet to organo and bio-stimulants. Here they used two organo- stimulants (PGRs) i.e, gibberellic acid @ 200 ppm and benzyladenine @ 50 ppm. The results revealed that, $\mathrm{GA}_{3} @ 200$ ppmincreased the plant height $(56.47 \mathrm{~cm})$ and total chlorophyll content (63.95 SPAD) compared to other treatments.

Lima et al. (2014) ${ }^{[25]}$ experimented on growth and yield of anthurium in response to gibberellic acid.Application of $\mathrm{GA}_{3}$ 
@ $150 \mathrm{ppm}, 300 \mathrm{ppm}$ and $450 \mathrm{ppm}$ promoted the total leaf area of the plant, where in maximum was found in $\mathrm{GA}_{3} @$ $450 \mathrm{ppm}\left(380.00 \mathrm{~cm}^{2}\right)$.

Deshmukh et al. (2014) ${ }^{[15]}$ conducted an experiment on effect of four $\mathrm{GA}_{3}$ at different concentrations i.e 0, 100, 200 and 300 $\mathrm{ppm}$ in african mariglod (Tagetets erecta L.). Among the different concentrations the maximum plant height $(53.95$ $\mathrm{cm})$, plant spread $\left(53.95 \mathrm{~cm}^{2}\right)$ and fresh weight plant ${ }^{-1}(375.85$ g) were observed in plants treated with $\mathrm{GA}_{3} @ 300$ ppm followed by $\mathrm{GA}_{3} @ 200$ ppm $\left(62.04 \mathrm{~cm}, 52.63 \mathrm{~cm}^{2}\right.$ and 346.87 g,respecctively).

Kesav (2014) ${ }^{[23]}$ carried out an experiment on the different growth regulators $\mathrm{GA}_{3} @ 100$ ppm and 200 ppm, NAA @ 25 ppm and 50 ppm and etherel @ 500 ppm and 800 ppm in african marigold (Tagetus erecta L.) cv. Pusa Narangi Gainda. Among the different growth regulators plants sprayed with GA3 @ 200 ppm recorded maximum plant height (84.79 $\mathrm{cm})$, plant spread $(50.56 \mathrm{~cm})$, number of primary branches plant $^{-1}$ (18.87), number of secondary branches plant ${ }^{-1}$ (45.72), total chlorophyll content (49.72 SPAD units), fresh weight plant $^{-1}(299.59 \mathrm{~g})$ and dry weight plant ${ }^{-1}(102.54 \mathrm{~g})$.

Raveendra et al. (2014) ${ }^{[38]}$ studied the influence of $\mathrm{GA}_{3} @$ $150 \mathrm{ppm}$ on 9 different varieties of daisy. Among the different treatments maximum plant height $(48.33 \mathrm{~cm})$, plant spread $(803 \mathrm{~cm} 2)$, number of leaves plant ${ }^{-1}(62.86)$, leaf area plant ${ }^{-1}$ $\left(557.33 \mathrm{~cm}^{2}\right)$ and number of suckers plant ${ }^{-1}$ (4.81) were recorded in plants sprayed with $\mathrm{GA}_{3} @ 150$ ppm in Purple long petal variety of daisy (Aster amellus L.).

Maitra and Roychowdhury (2015) ${ }^{[26]}$ verified the effect of three different levels (50 ppm, $75 \mathrm{ppm}$ and $100 \mathrm{ppm}$ ) of each of $\mathrm{BA}, \mathrm{GA}_{3}, \mathrm{NAA}$ and ethrel on carnation (Dianthus caryophyllus L.) cv. Chabaud Super Mix and they opined that growth regulators had a profound effect on the plant height of carnation and the longest plants were recorded as a result of application of $\mathrm{GA}_{3} @ 75 \mathrm{ppm}(75.28 \mathrm{~cm})$ whereas the shortest were from untreated plants $(59.78 \mathrm{~cm})$

Sharma and Joshi (2015) ${ }^{[46]}$ studied the effect of foliar spray of plant growth regulators viz., gibberellic acid $\left(\mathrm{GA}_{3} @ 150\right.$ ppm and 250 ppm) and 1-Naphthaleneacetic acid (NAA @ 25 and $50 \mathrm{ppm}$ ) on vegetative parameters on three china aster cultivars. They opined that maximum plant height $(56.18 \mathrm{~cm})$ and maximum leaf area $\left(3968.88 \mathrm{~cm}^{2}\right)$ was exhibited by the treatment $\mathrm{GA}_{3} @ 250 \mathrm{ppm}$ and least by NAA @ 50 ppm $(39.96 \mathrm{~cm})$.

Prakash et al. (2015) ${ }^{[35]}$ carried out an experiment on effect of different growth regulators i.e., GA 3 @ 100, 200 and 300 ppm, NAA @ 50,100 and 150 ppm, and BA @ 50,100 and 150 ppm, along with control (water spray) on chrysanthemum (Dendranthema grandiflora L.) cv. Vasantika. Among the growth regulators $\mathrm{GA}_{3} @ 300$ ppm recorded maximum plant height $(27.20 \mathrm{~cm})$, plant spread $(27.20 \mathrm{~cm})$ and number of primary branches (5.47) followed by $\mathrm{GA}_{3} @ 200$ ppm (60.07 $\mathrm{cm}, 25.67 \mathrm{~cm}, 5.07)$.

Singh and Nigam (2015) ${ }^{[50]}$ observed that plants sprayed with $\mathrm{GA}_{3} @ 250 \mathrm{ppm}$ recorded the maximum plant height $(58.60$ $\mathrm{cm}$ and $46.78 \mathrm{~cm})$, plant spread $(31.79 \mathrm{~cm}$ and $28.26 \mathrm{~cm})$, number of branches plant ${ }^{-1}(17.22$ and 20.87) in chrysanthemum cvs. Birbal Sahni and Julia.

Sethy et al. (2016) ${ }^{[43]}$ experimented the effect of plant growth regulators on growth and flowering of ornamental sunflower and the results of the study revealed that application of $\mathrm{GA}_{3}$ @ 200 ppm recorded significantly higher plant height (139.55 $\mathrm{cm})$ and minimum by MH @ 1500 ppm (50.86 cm) whereas application of $\mathrm{GA}_{3} @ 200$ ppm recorded significantly maximum number of leaves (26.66) in contrast to it, minimum (17.60) was recorded by MH @ 1500 ppm.

Reshmi and Sheela (2016) [39] conducted a study to standardize growth regulators for enhancing propagation efficiency in three exotic cultivars of heliconia. Two field trials were carried out for this purpose. Based on the results of the preliminary field trial, second experiment was laid out. Application of growth regulators had pronounced effect on sucker production at all the stages. During the first experiment, BA @ 750 ppm produced the highest number (4.19) of suckers/plant.In the second experiment, variation was evident in the total number of suckers. Here, BA @ 850 ppm produced the highest number (4.33) of suckers and it was on par with BA @ 700 ppm (4.00) and $\mathrm{GA}_{3} @ 650$ ppm (3.79).

Anuradha et al. (2017) ${ }^{[2]}$ conducted an experiment on effect of different plant growth regulators i.e water spray, GA3 @ 200 ppm, NAA@60 ppm, CCC @ 1000 ppm and TIBA@ $1000 \mathrm{ppm}$ in african marigold cv. Culcatta Orange. Among the different treatment's plants sprayed with GA3 @ 200 ppm recorded maximum plant height $(64.52 \mathrm{~cm})$, number of primary branches plant ${ }^{-1}(22.60)$ and number of secondary branches plant $^{-1}(53.25)$ at 90 DAT.

Mishra et al. (2018) ${ }^{[29]}$ studied foliar application of $\mathrm{GA}_{3}(50$, 100 and $150 \mathrm{ppm}$ ) with different spray frequencies (twice and thrice) on growth, flowering and yield of china aster (Callistephus chinensis L.) NEES. Among the different frequencies, maximum height $(69.03 \mathrm{~cm})$, number of primary branches plant ${ }^{-1}(15.63)$ and number of leaves plant ${ }^{-1}(302.81)$ were recorded in plants sprayed thrice with GA3 @ 100 ppm. Singh et al. (2018) ${ }^{[53]}$ carried out an experiment on effect of $\mathrm{GA}_{3}(50,100$ and $150 \mathrm{ppm})$ and $\mathrm{CCC}(1000,5000$ and 10000 ppm) on growth, flowering and yield of chrysanthemum (Dendranthema grandiflora Ramat) cv. Birbal Sahni. The maximum plant height $(58.60 \mathrm{~cm})$, plant spread $(31.79 \mathrm{~cm})$, number of branches plant ${ }^{-1}(17.22)$ and number of leaves plant $^{-1}$ (219.74) registered with $\mathrm{GA}_{3} @ 150$ ppm while minimum was recorded in control.

\section{Influence of plant growth regulators on flowering and quality cut flowers}

Beena (2000) ${ }^{[6]}$ investigated the effect of growth regulators on growth and flowering of Anthurium andreanum Linden. The varieties used were Liver Red, Ceylon Red and Kalympong Orange. Three growth regulators namely $\mathrm{GA}_{3}$, TIBA and $\mathrm{K}$ were used at $100 \mathrm{ppm}, 300 \mathrm{ppm}$ and $500 \mathrm{ppm}$ concentrations. The highest length of spadix $(43.52 \mathrm{~cm})$ was showed six months after the first spray by Liver Red treated with GA @ 500 ppm.

Dhekney et. al. (2000) ${ }^{[17]}$ reported that $\mathrm{GA}_{3}$ at $200 \mathrm{ppm}$ resulted an increase in bud length, bud circumference and flower diameter. They also stated that the maximum flower neck length $(9.07 \mathrm{~cm})$ was produced in rose cv. First Red by applying $\mathrm{GA}_{3} @ 300$ ppm while control recorded $6.43 \mathrm{~cm}$. They observed that applying $\mathrm{GA}_{3} @ 200$ ppm produced maximum number of flowers (38.61) per $\mathrm{m}^{2}$ compared to control (18.22).

Sadanand et. al. (2000) ${ }^{[40]}$ recorded increased bud length and bud diameter with $\mathrm{GA}_{3}$ application and the highest length and diameter were obtained in case of bud with $\mathrm{GA}_{3} @ 200$ ppm in rose cv. First Red.

Verma et. al. (2000) ${ }^{[58]}$ stated that applying nitrogen (500 $\mathrm{ppm})$ and $\mathrm{GA}_{3}(50 \mathrm{ppm})$ per week were found to be effective in increasing the flower diameter and flower length in carnation. 
Thamaraiselvi et. al. (2002) ${ }^{[56]}$ reported that applying calcium acetate 0.5 percent + Panchakaya 5 percent significantly improved the floral characters such as flower weight, flower length, flower thickness and petal number in Edward rose. Chandrappa (2002) ${ }^{[9]}$ studied the effect of growth regulators on growth characters of Anthurium cv. Royal Red. Among the different treatments $\mathrm{GA}_{3} @ 750$ ppm showed maximum (44.78) stalk length and $(7.02 \mathrm{~cm})$ spadix length whereas minimum (41.58) was observed in TIBA @ 500 ppm and minimum $(6.46 \mathrm{~cm})$ was observed in TIBA @ 500 ppm respectively.

Katkar et al. (2003) ${ }^{[22]}$ reported that plants sprayed with $\mathrm{GA}_{3}$ @ 200 ppm recorded minimum number of days to first flower bud emergence (56.26) and days to 50 percentflowering (80.46) in china aster (Callistephus chinensis) cv. California Giant Mix.

Chakradhar et. al. (2003) ${ }^{[8]}$ reported that flower bud length and diameter were maximum with application of $\mathrm{GA}_{3} @ 60$ ppm and minimum with BA @ 100 ppm in rose cv. Gladiator. Significantly maximum flower diameter $(7.09 \mathrm{~cm})$ was recorded@ GA $@ 100$ ppm with DSF @ 75 percent of RDF in China aster as compared to control $(4.87 \mathrm{~cm})$

Preeti et al. (2004) ${ }^{[36]}$ studied the effect of different plant growth regulators i.e. $\mathrm{MH}(500 \mathrm{ppm}$ and $1000 \mathrm{ppm}), \mathrm{GA}_{3}$ (300 ppm and $500 \mathrm{ppm})$, BAP (200 ppm and $400 \mathrm{ppm})$, ethylene (500 ppm and $750 \mathrm{ppm})$ and IAA (200 ppm and 300 ppm) on floral characters of Anthurium andreanumcv. Agnihotri and they opined that among different plant growth regulators $\mathrm{GA}_{3} @ 500$ ppm recorded early to full bloom (26.13 days) which is at par with $\mathrm{GA}_{3} @ 300$ ppm $(26.20$ days) and BAP @ 400 ppm (26.53 days) whereas maximum days to full bloom was recorded by ethylene @ 750 ppm ( 30.40) andthe results also revealed that among different plant growth regulators $\mathrm{GA}_{3} @ 500$ ppm recorded maximum spathe length $(8.60 \mathrm{~cm})$, maximum spadix length $(6.00 \mathrm{~cm})$ and maximum stalk length $(36.67 \mathrm{~cm})$.

Srinivasa (2005) ${ }^{[54]}$ revealed the influence of $\mathrm{GA}_{3}$ on growth of anthurium cv. Mauritius Red. He opined that plants treated with $\mathrm{GA}_{3} @ 300$ ppm recorded maximum stalk length (44.44 $\mathrm{cm})$, spathe length $(7.81 \mathrm{~cm})$, spathe width (7.13) andspadix length $(6.49 \mathrm{~cm})$ compared to all other treatments.

Dhaduk et al. (2007) studied the effect of $\mathrm{GA}_{3}$ on growth and yield attributes in anthurium. Foliar spray of $\mathrm{GA}_{3} @ 500$ ppm, recorded maximum stalk length $(24.15 \mathrm{~cm})$ compare to other treatments.

Devadanam et. al. (2007) ${ }^{[16]}$ demonstrated that the effects of gibberellic acid (50, 100 or $150 \mathrm{ppm}$ ) on flowering of Polianthes tuberosa. GA 3 was sprayed to plants@30,60 and 90 day after planting significantly enhanced flower spike. $\mathrm{GA}_{3} @ 150$ ppm resulted in the greatest number of florets per spike (30.49), flower yield/ha (6.25), and number of spikes/ha (2.48 lakhs).

Tyagi and Singh (2008) [57] indicated that the effect of gibberellic acid $\left(\mathrm{GA}_{3}\right)$ and IBA on flowering of tuberose (Polianthes tuberosa. cv. Double.) There were 17 treatments of soaking at $24 \mathrm{~h}$ before planting and spraying at 30 days after planting of $\mathrm{GA}_{3} @(40,80,120$ and 160 ppm) and IBA at $\left(20,40,60\right.$ and 80 ppm). Spraying of $\mathrm{GA}_{3} @ 160$ ppm at 30 days after planting was the most effective for days emergence of spikes (80.33), florets per spike (38.85), spike diameter $(0.97 \mathrm{~cm})$, spikes per plant $(2.43)$, spike length $(78.33 \mathrm{~cm})$ and rachis length $(34.48 \mathrm{~cm})$.

Ismaeil and Youssef (2008) ${ }^{[21]}$ reported that all $\mathrm{GA}_{3}(50,100$ and 200ppm) treatments statistically increased the number of flowers/ clumps, Length and diameter of flower stalk, fresh and dry weights of flower as compared with control in both seasons.

Dalal et. al. (2009) ${ }^{[13]}$ demonstrated that the effects of gibberellic acid $(0,50,100$ and $150 \mathrm{ppm})$ on growth, flowering, yield and quality of gerbera under polyhouse conditions. $\mathrm{GA}_{3}$ was sprayed to plants at 30 and 60 day after transplanting. The result indicated that, maximum vegetative growth, flower yield and quality were observed with treatment of $\mathrm{GA}_{3}$ at $150 \mathrm{ppm}$. Whereas early flowering was noticed in plant sprayed with $50 \mathrm{ppm} \mathrm{GA}_{3}$.

Sajid et al. (2009) ${ }^{[42]}$ opined that foliar application of plant growth regulators and nutrients for improved the quality of lily flowers. It was found that floral stem length of the plants sprayed with nutrients alone increased by 25 percent $(78.00$ $\mathrm{cm})$ over those of the control plants $(62.50 \mathrm{~cm})$. Mean shoot length of the plants sprayed with both the $\mathrm{GA}_{3}(20 \mathrm{ppm})$ and nutrients increased by 33 percent $(82.00 \mathrm{~cm})$ over the control plants and by 6 percent over the other set of plants, which received the treatment of nutrients alone.

Hashemabadi and Zarchini (2010) ${ }^{[19]}$ evaluated the effect of different levels of salicylic acid, gibberellic acid and cycocel at pre-harvest stage on the quality, yield and vase life of cut rose (Rosa hybrida 'Poison'). The best treatment to increase the stem length of flower was $\mathrm{GA}_{3} @ 300$ ppm which produced longest stems $(49.33 \mathrm{~cm})$ whereas minimum was showed by CCC @ 1500 ppm $(29.93 \mathrm{~cm})$.

Pancholi et al. (2010) ${ }^{[33]}$ done with the experiment on response of Anthurium to foliar application of urea and growth regulators in shade net house and documented that compare to all other combinations, GA3 @ 150 ppm produced the maximum spathe length $(7.10 \mathrm{~cm})$ followed by BA @ 100 ppm $(6.20 \mathrm{~cm})$, whereas minimum was recorded by control $(4.10 \mathrm{~cm})$ and maximum spadix length $(3.50 \mathrm{~cm})$ followed by BA @ 100 ppm $(2.90 \mathrm{~cm})$ whereas minimum $(2.10 \mathrm{~cm})$ was recorded by control.

Soner and Osman (2010) ${ }^{[52]}$ concluded that the effect of foliar applications of $\mathrm{GA}_{3}$ and paclobutrazol on yield and quality parameters in goldenrod were investigated in the study. The study revealed that once and twice foliar applications of 250 $\mathrm{mg}$ of $\mathrm{GA}_{3}$ shortened the days to flower and increased stem length, stem diameter, stem fresh weight, number of secondary inflorescences and number of stems per plant. In addition, the paclobutrazol treatments slightly retarded the days to flower and significantly reduced stem length and stem weight.

Sharifuzzaman et al. (2011) ${ }^{[44]}$ studied the effect of $\mathrm{GA}_{3}$, $\mathrm{CCC}$ and $\mathrm{MH}$ on flower yield and quality of chrysanthemum. They revealed that with different treatment combinations. Length of flower stalk significantly increased when plant was treated with $\mathrm{GA}_{3}$ regardless of different concentrations. The application of $\mathrm{GA}_{3} @ 150$ ppm produced maximum length of flower stalk $(14.00 \mathrm{~cm})$. The minimum was shown by CCC @ 400 ppm (6.00).

Muthukumar et al. (2012) ${ }^{[31]}$ studied the influence of various growth regulating chemicals on growth, yield and quality characters of cut rose $c v$. First Red. The study involved preharvest spraying with gibberellic acid (50 and $100 \mathrm{ppm}$ ), maleic hydrazide (50 and $100 \mathrm{ppm}$ ) and salicylic acid (25 and 50 ppm). Gibberellic acid @ 100 ppm as a pre harvest spray excreted a significant influence on crop growth and recorded highest mean values for stalk length $(60.98 \mathrm{~cm})$ whereas minimum $(32.95 \mathrm{~cm})$ flower stalk length was recorded by maleic hydrazide @ 100 ppm. and also, the growth regulators $\mathrm{GA}_{3} @ 100$ ppm recorded maximum vase life (2.60 days) while least (1.10 days) was observed in control. 
Handaragall et al. (2013) ${ }^{[18]}$ studied on effect of GA3 and foliar nutrients along with bio fertilizers on growth and flowering of Anthurium andreanum cv. Tropical Red. Results showed that among the different treatments GA3 @ 100 ppm along with bio-fertilizers exhibited early days to flower bud appearance (61.20) and early days to flower opening (12.00). Rani and Singh (2013) ${ }^{\text {[37] }}$ conducted a trial on the effects of $\mathrm{GA}_{3}(50,100$ or $150 \mathrm{ppm})$ on growth, flowering and quality flower production of tuberose. It was concluded that $\mathrm{GA}_{3}$ at $150 \mathrm{ppm}$ proved to be best concentration in enhancing all the floral (spike length, number of florets/ spikes, floret length) and bulbous characteristics in tuberose. $\mathrm{GA}_{3}$ also resulted in early flowering and more durable flowers which are the major contributing traits for floriculture industries. Better performance of tuberose with application of $\mathrm{GA}_{3}$ might be due to efficient nutrient uptake, enhancing source and sink potential by promoting photosynthetic enzymes, leaf area, more trapping of light for increasing photosynthetic rate, proper metabolism of antioxidant enzymes to normal level.

Anjali (2013) ${ }^{[3]}$ evaluated the response of $\mathrm{GA}_{3}$ on growth and yield of anthurium (Anthurium andreanum Lind.) under shade net condition. Foliar application of $\mathrm{GA}_{3}$ had a significant effect on promotion of stalk length in different varieties. At the end of the experimental period (15 months after planting), the treatment $\mathrm{GA}_{3} @ 600$ ppm recorded maximum stalk length $(48.59 \mathrm{~cm})$, whereas minimum in case of $(42.84 \mathrm{~cm})$ control.At the end of the experiment (15 months after planting) the maximum spathe length $(12.61 \mathrm{~cm})$ and spadix length $(8.22 \mathrm{~cm})$ was recorded in treatment $\mathrm{GA}_{3} @ 600$ ppm and it was minimum $(10.70 \mathrm{~cm})$ in treatment control. In case of $\mathrm{GA}_{3} @ 600$ ppm also recorded maximum angle $\left(31.93^{\circ}\right)$ between spadix to spathe compare to control $\left(30.00^{\circ}\right)$.

Chauhan et al. (2014) ${ }^{[10]}$ studied the effect of gibberellic acid on flowering and cut flower yield in gerbera under protected condition. The results revealed that $\mathrm{GA}_{3} @ 100$ ppm increase the length of flower stalk $(54.32 \mathrm{~cm})$ which is at par with $\mathrm{GA}_{3}$ @ $150 \mathrm{ppm}(52.76 \mathrm{~cm})$ and in case $\mathrm{GA}_{3} @ 150 \mathrm{ppm}$ had maximum vase life of gerbera (10.00 days) which is on par with $\mathrm{GA}_{3} @ 100$ ppm (9.63 days).

Kesav (2014) ${ }^{[23]}$ conducted an experiment on the different growth regulators viz., $\mathrm{GA}_{3} @ 100$ ppm and 200 ppm, NAA @ 25 ppm and 50 ppm and etherel @ 500 ppm and 800 ppm in african marigold (Tagetus erecta L.) cv. Pusa Narangi Gainda. The minimum number of days taken for first flower bud appearance (22.83), first flower appearance (30.23), 50 percent flowering (42.06) and flower diameter $(7.50 \mathrm{~cm})$ were recorded in plants sprayed with $\mathrm{GA}_{3} @ 200$ ppm.

Munikrishnappa and Chandrashekar (2014) reported that maximum vase life was recorded with $\mathrm{GA}_{3} @ 200$ ppm (22.88 days) than control in china aster (Callistephus chinensis (L.) NEES.).

Raveendra et al. (2014) ${ }^{[38]}$ found that significantly minimum days to first flowering (62.00), number of days taken for 50 percentflowering (71.39) and maximum spike length (54.89 $\mathrm{cm}$ ) were observed in plants sprayed with $\mathrm{GA}_{3} @ 150 \mathrm{ppm}$ in daisy (Aster amellus L.).

Kumar et al. (2015) ${ }^{[35]}$ reported that the plants sprayed with $\mathrm{GA}_{3} @ 300$ ppm recorded early flower bud initiation (48 days), opening of first flower (89.87 days) and maximum length of flower stalk $(8.95 \mathrm{~cm})$ in china aster (Callistephus chinensis L. Nees) cv. Kamini

Parmar et al. (2015) ${ }^{[34]}$ experimented on effect of $\mathrm{GA}_{3}$ and CCC on flower yield of Dutch rose (Rosa hybrida Linn.) cv. Passion under polyhouse condition. The maximum (12.23 days) vase life of cut flower was exhibited by $\mathrm{GA}_{3} @ 200$ ppm

Huang et al. (2015) ${ }^{[20]}$ experimented to study the influences of different concentration of gibberellic acid on the flowering parameters in Remusatia vivipara. The results revealed that plants sprayed with $\mathrm{GA}_{3} @ 75$ ppm recorded maximum $(8.58$ $\mathrm{cm})$ spathe length

Baghele et al. (2016) ${ }^{[5]}$ evaluated the effect of foliar spray of growth regulators viz. $\mathrm{GA}_{3}(50,100$ and $150 \mathrm{ppm}), \mathrm{BA}(50$, 100 and $150 \mathrm{ppm})$, NAA (50, 100 and $150 \mathrm{ppm})$ and cow urine on growth of Rose (Rosa hybrida) cv. Poison under naturally ventilated polyhouse. All the treatment combination comprising of foliar spray significantly improved flower parameters and yield over control. Among all plant growth regulators and cow urine, the application of $\mathrm{GA}_{3} @ 100$ ppm showed maximum stalk length $(55.33 \mathrm{~cm})$ and it was on par with $\mathrm{GA}_{3} @ 150$ ppm $(4.65 \mathrm{~cm})$ and BA @ 150 ppm $(52.58$ $\mathrm{cm})$ and application of $\mathrm{GA}_{3} @ 100$ ppm showed maximum vase life (9.87 days) followed by $\mathrm{GA}_{3} @ 150$ ppm (9.27 days) and BA @ 150 ppm (8.27 days).

Anuradha et al. (2017) ${ }^{[2]}$ recorded the minimum number of days taken for flower bud appearance (41.40), flower initiation (57.69) and maximum flower yield plant ${ }^{-1}$ (397.25 g) in the plants treated with $\mathrm{GA}_{3} @ 200$ ppm in african marigold cv. Culcatta Orange.

Cherik et al. (2017) ${ }^{[11]}$ observed the maximum vase life in the treatment $\mathrm{GA}_{3} @ 100$ ppm (14.80 days) in gerbera (Gerbera jamesonii L.) cv. Pink Elegance under naturally ventilated polyhouse.

Markam (2017) ${ }^{[27]}$ conducted an experiment on effect of different plant growth regulators i.e GA 3 @ 200 ppm and 300 ppm and CCC@1000 ppm and 1500 ppm. Significantly the minimum number of days taken for first harvest of flowers (50.26) was recorded in plants sprayed twice with $\mathrm{GA}_{3} @ 300$ ppm followed by of $\mathrm{GA}_{3} @ 200$ ppm at 25 and 45 DAT $(51.42 \mathrm{~d})$ in african marigold (Tagetes erecta L.) under Chhattisgarh plains.

Maurya et al. (2017) ${ }^{[28]}$ observed that plants sprayed with $\mathrm{GA}_{3} @ 150 \mathrm{ppm}$ recorded minimum number of days to first flowering (62.80), maximum number of flowers plant ${ }^{-1}$ (75.73) and flower diameter $(5.96 \mathrm{~cm})$ in china aster (Callistephus chinensis).

Choudhari et al. (2018) ${ }^{[12]}$ reported that plants sprayed with $\mathrm{GA}_{3} @ 150 \mathrm{ppm}$ recorded minimum number of days for first flowering (61.00), days for 50 percent flowering (71.33) and maximum flower stalk length $(60.17 \mathrm{~cm})$ and vase life $(3.78$ days) in cut chrysanthemum (Dendranthema grandiflora Tzevelev.) cv. Yellow Gold.

Sindhuja et al. (2018) ${ }^{[49]}$ observed that the foliar application of $\mathrm{GA}_{3} @ 200$ ppm recorded maximum flower diameter (6.21 $\mathrm{cm})$ and vase life (8.96 days) in china aster (Callistephus chinensis L. Nees) cv. Shashank.

Singh et al. (2018) ${ }^{[53]}$ reported that maximum flower Size $(4.29 \mathrm{~cm})$ and length of flower stalk $(8.46 \mathrm{~cm})$ were recorded with the foliar application of $\mathrm{GA}_{3} @ 150 \mathrm{ppm}$ in chrysanthemum (Dendranthema grandiflora Ramat) cv. Birbal Sahni.

\section{Influence of plant growth regulators on yield}

Chandrappa (2002) ${ }^{[9]}$ studied the effect of growth regulators on growth characters of anthurium cv. Royal Red. Among all the growth regulators $\mathrm{GA}_{3} @ 750$ ppm produced maximum no. flowers /plant (3.29), whereas minimum (2. 90 flowers/plant) was recorded by TIBA @ 500 ppm. 
Preeti et al. (2004) ${ }^{[36]}$ studied the effect of different plant growth regulators i.e. $\mathrm{MH}(500 \mathrm{ppm}$ and $1000 \mathrm{ppm}), \mathrm{GA}_{3}$ (300 ppm and $500 \mathrm{ppm}$ ), BAP (200 ppm and $400 \mathrm{ppm})$, ethylene (500 ppm and $750 \mathrm{ppm}$ ) and IAA (200 ppm and 300 ppm) on floral characters of Anthurium andreanum cv. Agnihotri. The results revealed that among different plant growth regulators $\mathrm{GA}_{3} @ 500$ ppm recorded maximum number of flowers/plant (3.80) which is at par with $\mathrm{GA}_{3} @$ 300 ppm (3.00) and BAP @ 200 ppm (2.93), whereas least (2.13) in case of control.

Srinivasa (2005) ${ }^{[54]}$ revealed the influence of $\mathrm{GA}_{3}$ on growth of anthurium cv. Mauritius Red. He opined that plants treated with $\mathrm{GA}_{3} @ 300$ ppm recorded maximum no. of flowers/plant (6.56) and maximum flower weight (37.56 g) compared to all other treatments.

Delvadia et al. (2009) ${ }^{[14]}$ experimented on the effect of different $\mathrm{GA}_{3}$ concentration and frequency on growth, flowering and yield in gaillardia (Gaillardia pulchella Foug.) $\mathrm{cv}$. Lorenziana and they opined that maximum number of flower yield (18.06 tons/ha), number of flowers/plant (150.48) and total weight of flowers/plant $(341.60 \mathrm{~g})$ was produced when plant treated with $\mathrm{GA}_{3} @ 250$ ppm at single stage and minimum was in control.

Sajid et al. (2009) ${ }^{[42]}$ opined that foliar application of plant growth regulators and nutrients greatly improved the yield of lily flowers. Mean number of flowers in control plants was 3.00 whereas in nutrients-fed plants, it was 3.50, which are 14 percent more than untreated plants. Number of flowers per plant in the set of plants, which received dual treatment $\left(\mathrm{GA}_{3}\right.$ + nutrients) was 4.50 , which are 50 percent more than control plants.

Hashemabadi and Zarchini (2010) ${ }^{[19]}$ evaluated the effect of different levels of salicylic acid, gibberellic acid and cycocel at pre-harvest stage on the quality, yield and vase life of cut rose (Rosa hybrida 'Poison'). Results showed that the highest record of flower yield was obtained by application of $\mathrm{GA}_{3} @$ $200 \mathrm{ppm}$ (192.00 cut flowers /year/ $\mathrm{m}^{2}$ and in case of maximum fresh weight $(47.35 \mathrm{~g})$ of flower was recorded by $\mathrm{GA}_{3} @ 150$ ppm and minimum (31.53 g) by CCC @ 500 ppm. Anburani and Vijay (2010) investigated that effect of growth retardants on growth and yield in nerium (Nerium odorum) and stated that among different growth retardants $\mathrm{MH} @ 1500$ ppm exhibited maximum number of flowers $(\mathrm{Kg}) /$ hectare (1074.07 Kg/ha) compared to CCC, ethrel and alar at different concentrations.

Pancholi et al. (2010) [33] done with the experiment on response of anthurium to foliar application of urea and growth regulators in shade net house and documented that compare to all other combinations (BA, GA 3 , Urea) $\mathrm{GA}_{3} @ 150$ ppm produced more number of flowers/plant (4.10) and least (2.00) was recorded by control

Bhatt and Chauhan (2012) ${ }^{[7]}$ investigated the effect of $\mathrm{GA}_{3}$ and BA on growth and flowering of Dendrobium cv. Sonia. It was observed that $\mathrm{GA}_{3} @ 15$ ppm showed maximum no. flowers/plant (6.00) compared to BA @ 15 ppm (4.00).

Kumar et al. (2012) ${ }^{[24]}$ conducted an experiment on effect of different growth regulators i.e MH @ 50 ppm and 100 ppm and $\mathrm{GA}_{3} @ 100$ ppm and 200 ppm on flowering and yield characters in african marigold. The results showed that foliar spray of $\mathrm{GA}_{3} @ 200$ ppm registered significantly maximum flower yield plant $^{-1}(639.18 \mathrm{~g})$.

Anjali (2013) ${ }^{[3]}$ evaluated the response of $\mathrm{GA}_{3}$ on growth and yield of anthurium (Anthurium andreanum lind.) under shade net condition. Different levels of $\mathrm{GA}_{3}$ sprayrecorded significantly higher yield at 12 to 15 months after planting.
Flower yield per square meter (22.77) and number of flowers per plant (3.25) were maximum in treatment $\mathrm{GA}_{3} @ 600$ ppm and minimum in control.

Handaragall et al. (2013) ${ }^{[18]}$ studied on effect of GA3 and foliar nutrients along with bio fertilizers on growth and flowering of Anthurium andreanum cv. Tropical Red. Results showed that among the different treatments. The maximum flower yield per $\mathrm{m}^{2}$ (34.00) were recorded in the plants treated with NPK 30:10:10 at 0.2 percent spray along with biofertilizers and $\mathrm{GA}_{3} @ 100$ ppm which was at par with NPK 15:0:10 at 0.2 percent spray + Azospirillum + Phosphobacteria +VAM+ GA 3 @ 100 ppm (30.35) and with NPK 30:10:10 at 0.2 percent spray + Azospirillum + phosphobacteria +VAM +GA 3 @ 200 ppm (28.33), while minimum flower yield per sq. $\mathrm{m}$ (15.45) were recorded in control.

Chauhan et al. (2014) ${ }^{[10]}$ studied the effect of gibberellic acid on flowering and cut flower yield in gerbera under protected condition. The results revealed that $\mathrm{GA}_{3} @ 100$ ppm increases the no. flowers/ sq. m (80.20) followed by $\mathrm{GA}_{3} @ 150$ ppm (79.80). whereas $\mathrm{GA}_{3} @ 100$ ppm increases the flower yield / hectare (16.04 lakh) followed by $\mathrm{GA}_{3} @ 150$ ppm (15.96 lakh).

Kesav (2014) [23] studied the effect of different growth regulators and pinching levels in african marigold (Tagetus erecta L.) cv. Pusa Narangi Gainda. The maximum number of flowers plant ${ }^{-1}$ (77.78) and fresh weight of flowers plant ${ }^{-1}$ $(577.90 \mathrm{~g})$ and flower yield hectare ${ }^{-1}(240.79 \mathrm{q})$ were recorded in plants sprayed with $\mathrm{GA}_{3} @ 200$ ppm.

Deshmukh et al. (2014) ${ }^{[15]}$ concluded that plants sprayed with $\mathrm{GA}_{3} @ 100 \mathrm{ppm}$ recorded the maximum yield of flowers $\operatorname{hectare}^{-1}$ (79.56 q) followed by $\mathrm{GA}_{3} @ 200$ ppm (77.85q) in african mariglod (Tagetets erecta $\mathrm{L}$.)

Prakash et al. (2015) ${ }^{[35]}$ concluded that foliar spray of $\mathrm{GA}_{3} @$ 300 ppm recorded maximum number of flowers plant ${ }^{-1}$ (59.0), flower yield plant ${ }^{-1}(149.39 \mathrm{~g})$, followed by GA 3 @ 200 ppm (49.80 and $106.28 \mathrm{~g}$ ) in chrysanthemum (Dendranthema grandiflora L.) cv. Vasantika.

Parmar et al. (2015) ${ }^{[34]}$ experimented on effect of $\mathrm{GA}_{3}$ and CCC on flower yield of dutch rose (Rosa hybrida Linn.) cv. Passion under polyhouse condition. Among different treatments $\mathrm{GA}_{3} @ 200$ ppm (140.33) produced maximum number of flowers/ sq. m. and produced more number of flowers/ hectare (14.03 lakh flowers) comparatively and also recorded (28.07) maximum number of flowers/plants.

Sharma and Joshi (2015) ${ }^{[46]}$ investigated the effect of foliar spray of plant growth regulators viz., $\mathrm{GA}_{3}(150 \mathrm{ppm}$ and 250 ppm) and NAA (25 ppm and $50 \mathrm{ppm}$ ) on floral parameters of three china aster cultivars and they concluded that $\mathrm{GA}_{3} @ 250$ ppm showed maximum (55.78) number of flowers/plants

Anuradha et al. (2017) ${ }^{[2]}$ concluded that the maximum flower yield plant ${ }^{-1}$ was recorded in $\mathrm{GA}_{3}$ at 200 ppm (397.25 g) than the control (165.50) in African marigold cv. Culcatta Orange. Mishra et al. (2018) ${ }^{[29]}$ concluded that three sprays of 100 ppm $\mathrm{GA}_{3} @(30,40$ \& $50 \mathrm{DAT})$ recorded maximum number of flowers plant ${ }^{-1}$ (77.04) while minimum number of flowers plant $^{-1}$ was recorded under control (61.81) in china aster (Callistephus chinensis L. NEES.)

Singh et al. (2018) ${ }^{[53]}$ reported that maximum number of flowers plant ${ }^{-1}(69.53)$ was recorded with foliar application of $\mathrm{GA}_{3} @ 150 \mathrm{ppm}$ in chrysanthemum (Dendranthema grandiflora Ramat) cv. Birbal Sahni.

\section{Conclusion}

Thus, from the present review concluded that use of $\mathrm{GA}_{3}$ helps in better growth, development, side-shoot production, 
earliness, flowering and post-harvest life of cut-flowers and loose flower. Gibberellic Acid $\left(\mathrm{GA}_{3}\right)$ has proven as a valuable production tools that can enhance product quality and marketability.

\section{References}

1. Anburani A. Vijay AA. Effect of growth retardants on growth and yield in nerium (Nerium odorum). J. Orn. Hort. 2010; 13(3):240-242.

2. Anuradha RW, Sateesh RP, Naveenakumar, Priyanka TK, Kulakarni BS. Effect of growth regulators on vegetative, flowering and flower yield parameters in African marigold cv. Culcatta Orange. Int. J. Pure and Applied Bio-sci. 2017; 5(5):636-640.

3. Anjali KB. Evaluation of varieties and studies on response of $\mathrm{GA}_{3}$ on growth, yield and quality of anthurium (Anthurium andreanum Lind.) under shade net condition. M.Sc. thesis, Univ. Hort. Sci., Bagalkot, Karnataka (India), 2013.

4. Aparna V. Effect of gibberellic acid on growth and flowering in chrysanthemum morifolium Ramat cvs. Thai Chen Queen and Snowball. M.Sc thesis, IARI, New Delhi, 2012.

5. Baghele RD, Dhaduk BK, Chawla SL, Radhika J. Effect of foliar spray of growth regulators and cow urine on flowering, quality and yield of rose (Rosa hybrida) cv. Poison under naturally ventilated polyhouse. Int. J. Trop. Agric. 2016; 34(6):1555-1558.

6. Beena R. Effect of growth regulators on the growth and flowering of anthurium. M. Sc. thesis, Univ. Agric. Sci., Thrissur, Kerala (India). 2000, 130.

7. Bhatt ST, Chauhan NM. Effect of $\mathrm{GA}_{3}$ and BA on growth and flowering. The Asian J. Hort. 2012; 7(1): 197-199.

8. Chakradhar M, Khirtkar SD. Rosh K. Effect of growth regulators on flower quality and vase life of rose cv. Gladiator. J. Soil and Crops. 2003; 13(2):374-377.

9. Chandrappa. Evaluation and effect of media, bio fertilizers and growth regulators on growth and flowering in anthuriums. Ph.D. thesis, Univ. Agric. Sci., Bangalore, Karnataka, 2002, 146.

10. Chauhan RV, Kava KP, Babariya VJ, Pansuria PB, Savaliya AB. Effect of gibberellic acid on flowering and cut flower yield in gerbera under protected condition. The Asian J. Hort. 2014; 9(2):404-407.

11. Cherik Z, Sangma N, Singh D, Fatmi U. Effect of plant growth regulators on growth, yield and flower quality of gerbera (Gerbera jamesonii L.) cv. Pink Elegance under naturally ventilated polyhouse. Int. J. Current Microbiology and Applied Sci. 2017; 6(10):468-476.

12. Choudhari R, Kulkarni BS, Shiragur M. Growth, flowering and quality of cut chrysanthemum (Dendranthema grandiflora Tzevelev.) cv. Yellow Gold, as influenced by different growth regulators. Int. J. Chem. Studies. 2018; 6(1):1458-1460.

13. Dalal SR, Soma AV, Anshi V, Karale GD. Effect of gibberellic acid on growth, flowering, yield and quality of gerbera under polyhouse conditions. Int. J. Agri. Sci. 2009; 5(2):355-356.

14. Delvadia DV, Ahlawat TR. Meena BJ. Effect of different $\mathrm{GA}_{3}$ concentration and frequency on growth, flowering and yield in gaillardia (Gaillardia pulchella Foug.) cv. Lorenziana. J. Hort. Sci. 2009; 4(1):81-84.

15. Deshmukh HN, Ramdevputra MV, Sahare HA. Effect of Spacing and gibberellic acid (GA3) on growth parameters and yield of african mariglod (Tagetets erecta L.) cultivars. Trends in bio-sci. 2014; 7(22):3622-3627.

16. Devadanam A, Sable PB, Shinde BN, Haldewad AM. Effect of foliar spray of plant growth regulators on growth and yield of tuberose (Polianthestuberosa). J. Mah. Agril. Univ. 2007; 32:282-283.

17. Dhekney SA, Ashok AD, Rangaswamy P. Effect of some growth regulating chemicals on growth and flowering of rose cv. First Red under greenhouse conditions. J. Orn. Hort. 2000; 3(1):51-53.

18. Handaragall AG, Jayanthi R, Rajendra BN. Effect of $\mathrm{GA}_{3}$ and foliar nutrients along with bio fertilizers on growth and flowering of anthurium (Anthurium andreanum Lind.) cv. Tropical red. The Asian J. 2013; Hort., 8(1):71-74.

19. Hashemabadi D Zarchini M. Yield and quality management of rose (Rosa hybrida cv. Poison) with plant growth regulators. Plant Omics J. 2010; 3(6):167-171.

20. Huang CT, Lin CL, Hsieh CF. Gibberellin-induced flowering in sexually defective Remusatia vivipara (Araceae). Taiwania. 2015; 60(1):1-7.

21. Ismaeil FHM, Youssef ASM. Effect of Gibberellic acid and stimufol fertilizer on growth and flowering of Hemerocallis aurantiaca plant. J. Bio. Chem.Environ. Sci. 2008; 3(4):421-448.

22. Katkar PB, Naik DM, Boodamwad SG, Gharat SN. Influence of plant growth regulators on flowering, quality and yield of flower in china aster cv. California Giant Mix. South Indian Hort. 2003; 53(6):378-381.

23. Kesav CR. Studies on effect of pinching and growth regulators and growth, flowering and yield of african marigold (Tagetus erecta L.) cv. Pusa Narangi Gainda, M.Sc thesis, Indira Gandhi krishi vishwa vidyalaya, Raipur, 2014.

24. Kumar R. Ram M, Gaur GS. Effect of GA3 and ethrel on growth and flowering of african marigold cv. Pusa Narangi Gainda. Indian J. Hort. 2012; 67:362- 366.

25. Lima JD, Ansante NF, Nomura ES, Fuzitani EJ, Modenese SH, Silvai G. Growth and yield of anthurium in response to gibberellic acid. Ciência Rural. 2014; 44(8):1327-1333.

26. Maitra S, Roychowdhury N. Effect of plant growth regulators on growth, development and flowering of carnation (Dianthus caryophyllus L.) Cv. chabaud super mix. J. Agric. Technol. 2015; 2(2):72-78.

27. Markam PS. Studies on the effect of plant growth regulators on growth, flower yield and quality of african marigold (Tagetes erecta L.) under chhattisgarh plains. Ph. D. Thesis. Indira Gandhi Krishi Vishwavidyalaya, Raipur, 2017.

28. Maurya R, Singh SP, Singh AK. Effect of $\mathrm{GA}_{3}$, Alar and BA on Flowering and Vase Life in china aster (Callistephus chinensis). Int. J. Current Microbio. and Applied Sci. 2017; 6(12):3148-3151.

29. Mishra PP, Pandey G, Kumura A, Naik R, Pujahari LP. Effect of foliar application of gibberellic acid (GA3) concentrations and spraying frequencies on vegetative and floral attributes of china aster (Callistephus chinensis L. NEES.). Int. J. Current Microbio. and Applied Sci. 2018; 7(1):1889-1894.

30. Munikrishnappa PM, Chandrashekar SY. Effect of growth regulators on growth and flowering of china aster (Callistephus chinensis (L.) NEES.). Agri. Reviews. 2014; 35(1):57-63. 
31. Muthukumar S, Ponnuswami V, Jawaharlal M, Ramesh AK. Effect of plant growth regulators on growth, yield and exportable quality of cut roses. Int. Quarterly J. Life Sci. 2012; 7(4):733-738.

32. Panwar R, Rinne T, Hansen E, Juslin H. Corporate Responsibility. Balancing Economic, Environmental, and Social Issues in the Forest Industry. Forest Products J. 2006; 56(2):4-12.

33. Pancholi BY, Desai JR, Saravaiya SN, Patel NM, Patel, RB. Response of anthurium to foliar application of urea and growth regulators in shade net house. The Asian J. Hort. 2010; 5(1):203-207.

34. Parmar AR, Chovatia RS, Karetha KM. Effect of plant growth regulators on flower yield, vase life and economics of dutch rose (Rosa hybrida Linn.) cv. 'PASSION' under polyhouse condition. The Asian J. Hort. 2015; 10(2):286-291.

35. Prakash S, Singh AK, Kumar M, Singh B. Effect of plant growth regulators on growth and flowering behavior of chrysanthemum (Dendranthema grandiflora L.) cv. Vasantika. Ann., Plant and Soil Res. 2015; 17:23-24.

36. Preeti H, Machahary RK, Sangita D, Bharali R. Production of quality Anthurium andreanum Lind. as affected by some regulating chemicals. Paper presented In: National Seminar Hort. Sust. Income Environ, 2004, 347-351

37. Rani $P$, Singh $P$. Impact of gibberellic acid pre-treatment on growth and flowering of tuberose (Polianthes tuberosa L.) cv. Prajwal. J. Trop. Plant Physiol. 2013; 5(1):33-41.

38. Raveendra YC, Shirol AM, Kulkarni BS. Influence of gibberellic acid on growth, yield and quality of daisy (Aster amellus L.) genotypes. Indian J. Agri. Res. 2014; 48(4):319-323.

39. Reshmi CR, Sheela VL. Effect of growth regulators on sucker production in exotic varieties of heliconia. J. Plant Agric. Res. 2016; 2(1):1-9.

40. Sadanand DA, Ashok AD, Rangaswamy P. Effect of some growth regulating chemicals on growth and flowering of rose cv. First Red under greenhouse conditions. J. Orn., Hort. 2000; 3(1):51-53.

41. Sainath, Uppar DS, Meena MK. Effect of different plant growth regulators on growth, quality, yield and yield components in chrysanthemum (Chrysanthemum coronarium L.). Int. J. Plant Sci. 2012; 7(1):10-17.

42. Sajid GM, Kaukab M, Ahmad Z. Foliar application of plant growth regulators and nutrients for improvement of lily flowers. Pak. J. Bot. 2009; 41(1):233-237.

43. Sethy H, Patra SK. Mohanty CR. Effect of plant growth regulators on growth and flowering of ornamental sunflower. Int. J. Agric. Sci. Res. 2016; 6(3):561-568.

44. Sharifuzzaman SM, Ara KA, Rahman MHK, Kabir. Talukdar MB. Effect of GA3, CCC and $\mathrm{MH}$ on vegetative growth, flower yield and quality of chrysanthemum. Int. J. Expt. Agric. 2011; 2(1):17-20.

45. Shanan NT, Abou-Zeid MY, El-Sadek ZH. Response of Celosia cristata cv. red velvet plant growth and floral performance to organo and bio- stimulants. World J. Agric. Sci. 2014; 10(4):146-153.

46. Sharma MK, Joshi KI. Effect of foliar spray of $\mathrm{GA}_{3}$ and NAA on growth, flowering and yield of china aster (Callistephus chinensis NEES) cultivars. Int. J. Agri. Sci. Res. 2015; 5(4):105-110.

47. Shinde KH. Investigation of different levels of gibberellic acid (GA3) and pinching treatments on growth, flowering and yield of Chrysanthemum (Chrysanthemum morifolium R.) cv. IIHR-6 under middle Gujarat conditions. M.Sc. thesis. Anand Agri. Univ., Gujarat, 2010.

48. Shinde KH, Parekh NS, Upadhyay NV, Patel HC. Investigation of different levels of gibberellic acid (GA3) and pinching treatments on growth, flowering and yield of Chrysanthemum (Chrysanthemum morifolium R.) cv. IIHR-6 under middle Gujarat conditions. Asian Hort. 2010; 5(2):416-419.

49. Sindhuja M, Prasad VM, Koradakera V. Effect of different plant growth regulators and their levels on floral yield and vase life of china aster (Callistephus chinensis L. NEES) cv. Shashank. Int. J. Current Microbio. and Applied Sci. 2018; 7(1):3391-3396.

50. Singh J, Nigam R. Effect of plant growth regulators and inorganic fertilizers on vegetative growth and flowering behaviour of Chrysanthemum Hort. Flora. Res. Spectrum. 2015; 4(3):273-276.

51. Soad, Ibrahim M, LOBNA M, Taha S, Farahat MM. Vegetative growth and chemical constituents of croton plants as affected by foliar application of benzyl adenine and gibberellic acid. J. Am. Sci. 2010; 6(7):126-130.

52. Soner K, Osman K. Influence of Growth Regulators on the Growth and Flowering Characteristics of Goldenrod (Solidago x Hybrida). European J. Sci. Res. 2010; 4(3):498-507.

53. Singh J, Nigam R, Singh R, Kumar A, Kumar A. Effect of gibberellic acid and cycocel on growth, flowering and yield of chrysanthemum (Dendranthema grandiflora Ramat.) cv. Birbal Sahni. J. Pharmacognosy and Phytochemistry. 2018; 2753-2758.

54. Srinivasa V. Influence of $\mathrm{GA}_{3}$ on growth and flowering in anthurium cv. Mauritius Red. Crop Res. 2005; 30(2):279-282.

55. Taha AR. Effect of Some Growth Regulators on Growth, Flowering, Bulb Productivity and Chemical Composition of Iris Plants. J. Hort. Sci.\& Orn. Plants. 2012; 4(2):215220.

56. Thamaraiselvi SP, Chezhiyan M, Ramar A. Studies on the effect of growth regulators, calcium, boron and organics on rose. South Indian Hort. 2002; 50(4-6):430436.

57. Tyagi AK, Singh CN. Effect of $\mathrm{GA}_{3}$ and IBA on growth and flowering of tuberose cv. Double. Prog. Agr. 2008; 8:25-26.

58. Verma VK, Sengal OP, Dhiman SR. Effect of nitrogen and $\mathrm{GA}_{3}$ on carnation. J. Orn. Hort. 2000; 3(1):64. 